\title{
Materiaty Karola Górskiego dotyczące BŁ. BroNiSŁaWA MaRKIEWICZA I WYCHOWANKÓW W Zasobie Archiwum Generalnego Zgromadzenia Świętego Michala Archaniola w Markach
}

słow a klu c z ow e: Karol Górski, Bronisław Markiewicz, Józef Pelczar, Walerian Moroz, Księża Michalici, duchowość michalicka, Miejsce Piastowe, zasób Archiwum Generalnego Zgromadzenia Świętego Michała w Markach

k e y w ord s: Karol Gorski, Bronislaw Markiewicz, Jozef Pelczar, Walerian Moroz, Michaelite Fathers, Michaelite spirituality, Miejsce Piastowe, Archive of the General Congregation of Saint Michael the Archangel in Marki

Abstract

Artykuł jest charakterystyką prac naukowych i materiałów naukowo-badawczych Karola Górskiego, przechowywanych obecnie w Archiwum Generalnym Zgromadzenia Świętego Michała Archanioła w Markach k. Warszawy. Materiały te umożliwiają poznanie życia i działalności bł. Bronisława Markiewicza założyciela (Zgromadzenia Świętego Michała Archanioła), jego pierwszych wychowanków oraz historii michalickiego Zakładu Wychowawczego w Miejscu Piastowym. 


\section{UWAGI WSTĘPNE}

Istnieje wiele powodów, aby zasłużyć sobie na powszechne uznanie. Przybliżenie sylwetki Profesora Karola Górskiego (1903-1988) ma swoje uzasadnienie z dwóch powodów. Pierwszy to jego naukowy, prekursorski dorobek, związany z historią życia duchowego. Drugi to jego etyczno-moralna postawa, godny wzorzec do naśladowania. Profesor K. Górski zainspirował mnie z tych powodów. Z jego dorobkiem zetknąłem się w Archiwum Generalnym Zgromadzenia św. Michała Archanioła w Markach-Strudze. Wówczas natrafiłem na jego rękopisy, opracowania w formie maszynopisów i korespondencję oraz wydawane przez niego publikacje. Pisanie o K. Górskim jest inspirujące także dla archiwisty. Zakres niniejszego opracowania opiera się głównie na dokumentach archiwalnych, przechowywanych w dwóch teczkach, które Profesor przekazał do archiwum Michalitów 7 kwietnia 1987 r. ${ }^{1}$ Pozyskana dokumentacja od K. Górskiego obejmuje swoim zakresem historię Zgromadzenia w jego początkach i biografię jego Założyciela, błogosławionego Bronisława Markiewicza (1842-1912). Podstawa źródłowa jest zawarta w jego odręcznych notatkach badawczych, zredagowanych w celu analizy i wyprowadzenia syntetycznych wniosków. Godne uwagi są także jego opracowania w formie maszynopisów i korespondencja, szczególnie z ks. Walerianem Morozem CSMA (1919-2005).

Przedstawione źródła stanowią zatem część historii życia i działania K. Górskiego, która nie była badana i nie jest znana szerokiemu gronu czytelników. Uznałem, że postać K. Górskiego zapisała się w dobrych relacjach z Księżmi Michalitami, szczególnie wówczas, gdy prowadził badania naukowe dotyczące historii Zgromadzenia i sylwetki duchowej bł. B. Markiewicza.

Profesor K. Górski należał do grona wybitnych historyków i był również doskonałym znawcą duchowości chrześcijańskiej. Publikował dzieła poświęcone zagadnieniom duchowości, m.in.: Zarys dziejów duchowości w Polsce².

1 Nazwa archiwum: Archiwum Generalne Zgromadzenia św. Michata Archaniota w Markach-Strudze (skrót AG-CSMA). Nazwa zespołu: Dokumentacja archiwalna od Karola Górskiego (symbol 88121167175). Teczka pierwsza posiada oryginalny tytuł: Korespondencja p. prof. Karola Górskiego dnia 7 IV 1987 r. przekazat Ks. Józefowi Grucy. Tytuł drugiej teczki jest taki sam jak pierwszej, nadany w Archiwum Generalnym Zgromadzenia w Markach.

2 K. Górski, Zarys dziejów duchowości w Polsce, Kraków 1986. 
Celem niniejszej publikacji jest prezentacja jego naukowej spuścizny, zwłaszcza z dziedziny duchowości Księży Michalitów.

Niewątpliwie K. Górski posiadał umiejętność wnikliwej oceny. Potrafił odróżnić ludzi świętych od tych, którzy ze świętością nie mają nic wspólnego. Swoje opinie budował na podstawie badań naukowych i obserwacji. W jego notatkach znajdują się stwierdzenia, że umiejętność akceptacji upokorzeń ze strony innych osób stanowi kolejne szczeble w zdobywaniu świętości. I w tym, jak pisał, zaznacza się przestrzeń pomiędzy świętością a szczytem doskonałości, która uwyraźnia duchowe wyrzeczenie się woli własnej. W tę przestrzeń wpisują się relacje pomiędzy przełożonymi a podwładnymi. Mówi się wówczas, że zdobywanie świętości dokonuje się w sytuacji, kiedy zarządzenia pierwszych niszczą własną wolę drugich. Są różne drogi zdobywania świętości. Droga świętości przełożonych to z reguły akceptacja upokorzeń, płynących od podwładnych, i akceptacja własnych niedoskonałości.

Archiwum dysponuje pokaźnym zasobem wiedzy na temat, jak bł. B. Markiewicz wzrastał do opinii świętości. K. Górski, opisując sylwetkę Błogosławionego Założyciela Księży Michalitów, dawał swoje świadectwo wielokrotnie w słowie drukowanym, wyrażając głębokie przekonanie o jego świętości. Także oceniając swój wkład, autor pisał, że zaangażował się osobiście w proces beatyfikacji i włożył weń dużo pracy w trakcie jego przebiegu ${ }^{3}$.

Odwołując się do wspomnień ze spotkania z ks. Prymasem Augustem Hlondem w 1945 r., wskazał, że rozmawiali o kandydatach na ołtarze i historii życia wewnętrznego. Profesor K. Górski zauważył, że Prymas na znak szacunku i czci w rozmowie o bł. B. Markiewiczu, który był kandydatem na ołtarze, uchylił piuski. Było to owocne spotkanie. Podczas rozmowy z Prymasem, K. Górski zwrócił uwagę a konieczność zadbania o formację wspólnot małżeńskich i ich obronę, praktykując np. rodzinną modlitwę różańcową oraz materialne wsparcie, np. poprzez szeroko zakrojoną działalność charytatywną ${ }^{4}$.

Wśród licznych publikacji o K. Górskim na uwagę zasługują następujące opracowania: Karol Górski - cztowiek i uczony pod red. Zenona Huberta Nowaka i Karol Górski - cztowiek i uczony, część II pod red. Mariana Biskupa

3 88121167175, Korespondencja p. prof. Karola Górskiego dnia 7 IV 1987 r. przekazat Ks. Józefowi Grucy, zob. K. Górski, Czcigodny Księże Asystencie, 11 wrzesień 1984 r.

4 88121167175, Korespondencja p. prof. Karola Górskiego dnia 7 IV 1987 r. przekazat Ks. Józefowi Grucy, zob. K. Górski, Wspomnienia ze spotkań i rozmów z Ks. Prymasem Augustem HLONDEM, 11 wrzesień 1982 r., s. 3-6. (maszynopis) 
i Janusza Tandeckiego5. Ważnym źródłem, z którego można się dowiedzieć o K. Górskim, jest jego Autobiografia naukowa, w której Profesor sam napisał o sobie, w jaki sposób doszedł do dojrzałości swojego człowieczeństwa jako badacz i naukowiec ${ }^{6}$. Również o K. Górskim dowiadujemy się z kolejnego opracowania autorstwa Karola Górskiego i Antoniego Bazielicha CSsR, Robimy nie dla siebie, ani dla względu ludzkiego, ale dla zasady, Korespondencja $1952-1988 .^{7}$

\section{Karol Górski JaKo NAUKOWIEC I BADACZ}

Karol Górski, syn Kazimierza i Anastazji, urodził się 30 kwietnia 1903 roku. Wychował się w rodzinie inteligenckiej. Ojciec był lekarzem, a matka zajmowała się grą na fortepianie. W Odessie uczęszczał do szkoły prywatnej i zdobył w niej solidne wykształcenie. Studiował trzy języki obce: angielski, francuski i niemiecki w domu, zanim trafił jako jedenastolatek do szkoły rosyjskiej. Odzyskanie niepodległości przez Polskę było dla rodziny Górskich okazją do zamieszkania w Milanówku k. Warszawy. W1919 r. K. Górski rozpoczął naukę w prywatnym gimnazjum Kazimierza Kulwiecia, a ojciec podjął pracę w Ministerstwie Pracy i Opieki Społecznej w Warszawie. K. Górski zdobył maturę w 1921 r. i rozpoczął studia z historii na Uniwersytecie Jagiellońskim w Krakowie. Rozwijał także swoje zainteresowania w dziedzinie społeczno-ekonomicznej, które w latach międzywojennych były szczególnym przedmiotem dociekań naukowych. Zainteresowania w czasie studiów dziedziną polityki, jak sam stwierdził, odrzucił ze względu na swoją naiwność i postanowił zdecydowanie podążać w kierunku rozwoju nauki. Doktoryzował się na podstawie rozprawy pt. Ród Odroważów w wiekach średnich, a promocja doktorska odbyła się 9 marca 1927 roku$^{8}$. Po uzyskaniu stopnia naukowego jesienią, K. Górski został powołany do służby wojskowej, którą odbył w latach 1927-1928 w Grudziądzu. W 1930 r. wstąpił w związek małżeński.

5 Pod red. Z. H. Nowaka, Karol Górski-cztowiek i uczony, Toruń 1999; pod red. M. Biskupa i J. Tandeckiego, Karol Górski - cztowiek i uczony, cz. 2, Toruń 2004.

6 K. Górski, Autobiografia naukowa, Toruń 2003.

7 K. Górski, A. Bazielich CSsR, Robimy nie dla siebie, ani dla względu ludzkiego, ale dla zasady, Korespondencja 1952-1988, Toruń 2006.

8 Z. H. Nowak, Karol Górski - koleje życia, [w:] Karol Górski - cztowiek i uczony, pod red. Z. H. Nowaka, Toruń 1999, s. 7-9. 
Jego żoną została Zofia Lipkowska, nauczycielka geografii, poznana przez niego jeszcze w czasie pobytu w Odessie. Nawiązał też bliskie kontakty z Akcją Katolicką, której patronem był wówczas ks. Prymas A. Hlond.

Wkrótce napisał rozprawę habilitacyjną pt.: Pomorze $w$ dobie wojny 13-letniej, opublikowaną w 1932 roku. Zatwierdzenia pracy habilitacyjnej doczekał się z początkiem 1933 roku. Jeszcze w tym samym roku, we wrześniu, uczestniczył w VII kongresie międzynarodowym nauk historycznych w Warszawie. Zainteresowania naukowe K. Górski rozwijał intensywnie, o czym świadczą podjęte tematy badawcze „Szlachta chełmińska w XV w.” i „Starostowie malborscy XV w."

Traumatycznym okresem dla K. Górskiego była druga wojna światowa. Po kapitulacji Warszawy został ciężko ranny i wzięty do niewoli niemieckiej. K. Górski był wyróżniony wysokimi odznaczeniami wojskowymi i państwowymi, np. za udział w kampanii wrześniowej otrzymał Srebrny Krzyż Orderu Virtuti Militari.

Okres powojenny to nowy etap życia K. Górskiego. Z początkiem lutego 1945 r. zamieszkał z żoną w Poznaniu, a od maja 1946 roku w Toruniu. K. Górski był prawym człowiekiem. Odznaczał się głęboką religijnością. W 1967 r. otrzymał specjalne zaproszenie ówczesnego ks. kardynała arcybiskupa krakowskiego, Karola Wojtyły, na kongres apostolatu do Rzymu, z którego jednak nie mógł skorzystać ze względu na zobowiązania naukowe i stan zdrowia. Przejście K. Górskiego na emeryturę w 1973 r. nie zmieniło jego dotychczasowego życia i nadal zajmował się sprawami naukowymi, pracując do śmierci, czyli do 11 grudnia 1988 roku?

K. Górski wydawał drukiem dzieła poświęcone życiu duchowemu, w których szczegółowo badał rozwój życia wewnętrznego bł. B. Markiewicza. O wnikliwej dbałości naukowej K. Górskiego świadczy publikacja pt.: Życie wewnętrzne ks. Bronistawa Markiewicza. W dziele autor obejmuje w skrócie życie Błogosławionego od czasu jego urodzenia 13 lipca 1842 r. w Pruchniku k. Jarosławia. Rysuje również panoramę ówczesnego zaboru austriackiego, gdzie w Miejscu Piastowym bł. B. Markiewicz prowadził szeroko zakrojoną działalność. Jako wytrawny znawca problemu osadza duchowość bł. B. Markiewicza w starej literaturze XVII i XVIII w. szczególnie w duchowości igna-

9 Tamże, s. 17-19; ponadto, K. Górski, Autobiografia naukowa, Toruń 2003, s. 15-75; także, K. Górski, A. Bazielich CSsR, Robimy nie dla siebie, ani dla względu ludzkiego, ale dla zasady, Korespondencja 1952-1988, Toruń 2006, s. 3-10. 
cjańskiej. Następnie analizuje „zapiski” życia wewnętrznego bł. B. Markiewicza i czyni szczegółowe komentarze, które są zakorzenione w problematyce duchowości, m. in. wspomina o walce $\mathrm{z}$ acedią, czyli smutkiem, duchowym lenistwem. Omawia odprawiane przez bł. B. Markiewicza rekolekcje m.in. w Starej Wsi k. Brzozowa u Ojców Jezuitów, w Mościskach u Ojców Redemptorystów. Autor omawianej publikacji w jej końcowej części podaje streszczenie duchowości bł. B. Markiewicza w następujących słowach: pokora, cierpliwość, posłuszeństwo, miłość Boga i bliźniego. Wreszcie stwierdza stanowczo, że wspominany bohater jest twórcą własnej szkoły duchowości, która cechuje się pokorą, ubóstwem, żarliwą miłością Boga i bliźniego. K. Górski na łamach swojego opracowania mówi również o bł. B. Markiewiczu jako zwolenniku kultu Najświętszej Maryi Panny, Królowej Polski ${ }^{10}$.

W następnym opracowaniu K. Górskiego pt. Duchowość chrześcijańska wspomina, że bł. B. Markiewicz jest jedną z najciekawszych postaci z przełomu XIX i XX wieku. Autor podaje, że na duchowość bł. B. Markiewicza wpływały „ćwiczenia” św. Ignacego, pisma św. Alfonsa Liguori, św. Franciszka Salezego i św. Jana Bosko ${ }^{11}$.

Zainteresowanie badawcze K. Górskiego osobą bł. B. Markiewicza było szczególne, ponieważ w opracowaniu pt. Studia i materiaty z dziejów duchowości poświęcił dużo miejsca na temat rozważań, dotyczących życia wewnętrznego bł. B. Markiewicza. Autor wyznacza sobie cel zbadania ewolucji, jaką przechodził bł. B. Markiewicz w swoim życiu duchowym od wyjazdu do Włoch w 1885 r. do 1911 r., i przyjmuje metodę badawczą chronologiczną. Dużo miejsca poświęca „zapiskom” życia duchowego bł. B. Markiewicza, czyniąc z nich podstawę do szczegółowej analizy, co może świadczyć o szczególnym zainteresowaniu i odpowiednim materiale warsztatu badawczego. Rezultatem dociekań naukowych Profesora jest określenie duchowości bł. B. Markiewicza w czterech punktach: 1) pokora, 2) cierpliwość, 3) posłuszeństwo, 4) miłość Boga i bliźniego ${ }^{12}$.

Postać bł. B. Markiewicza była wyjątkowo zanana K. Górskiemu, czego dowodzi wspólne opracowanie z ks. Mieczysławem Głowackim CSMA zapisków jego życia wewnętrznego. Było to pierwsze wydanie tekstów w dwóch językach: łacińskim i polskim, wydrukowanych w czasopiśmie „Nasza Prze-

${ }^{10}$ K. Górski, Życie wewnętrzne ks. Bronistawa Markiewicza, „Nasza Przeszłośc”, t. 23, 1966, s. 239-278.

${ }^{11}$ K. Górski, Duchowość chrześcijańska, Wrocław 1978, s. 258-259.

12 K. Górski, Studia i materiaty z dziejów duchowości, Warszawa 1980, s. 319-361. 
szłość"13. Opublikowane przez K. Górskiego źródło, obejmujące lata 1866-1891, dowodzi o głębokim duchowym życiu bł. B. Markiewicza. Analiza treści „zapisków” świadczy o tym, że K. Górski rzetelnie podszedł do pracy wraz z całym bogactwem swojej wiedzy i doświadczenia naukowego, dotyczącego problematyki duchowości.

Książka K. Górskiego pt. Zarys dziejów duchowości w Polsce, wydana w Krakowie, wspomina bł. B. Markiewicza i jego duchowość. Autor podkreśla, że do 1885 roku bł. B. Markiewicz pozostawał pod wpływem duchowości ignacjańskiej. Duchowość opierał na podstawach żarliwej miłość do Boga i bliźniego, pokorze i ubóstwie ${ }^{14}$.

\section{NotatKI ODRĘCZNE I MASZYNOPISY Karola GórSKIEgo}

K. Górski związany był ze środowiskiem naukowym Uniwersytetu Mikołaja Kopernika w Toruniu, stąd znany był również Księżom Michalitom pełniącym służbę duszpasterską w Toruniu od 1939 roku. Przykładem współpracy było wyposażenie biblioteki zakonnej w periodyki naukowe przez K. Górskiego w 1973 roku ${ }^{15}$. Ożywienie kontaktów między K. Górskim i władzami Zgromadzenia, jak wskazuje korespondencja, nastąiło w czasie starań o beatyfikację obecnie już bł. B. Markiewicza. Świadczą o tym również opublikowane opracowania K. Górskiego, dotyczące świętości osoby Założyciela Zgromadzenia Księży Michalitów.

Zaangażowanie K. Górskiego w analizowanie dzieła opiekuńczego wychowywania bł. B. Markiewicza widać w licznych notatkach, gdzie m.in. na jednej kartce zapisanej z obydwu stron autor zawarł szczegółowe daty z jego działalności od „1893 Początek Zakładu” do 1906 roku$^{16}$. Kolejne kartki informują o wnikliwej analizie Zgromadzenia od 1902 r., uwzględniającego tok wydarzeń i kolejność następstw. Zakres badań dotyczył także pierwszych

13 K. Górski i M. Głowacki, ks. CSMA, Zapiski dotyczące życia wewnętrznego, „Nasza Przeszłość," t. 54, 1980, s. 13-149.

14 K. Górski, Zarys dziejów duchowości w Polsce, s. 364-365.

15 GDZMS, Dom i parafia w Toruniu ul. Rybaki 59, SPRAWOZDANIE ZE STANU I DZIAEALNOŚCI PLACÓWKI Zgromadzenia św. Michata Archaniota w Toruniu przy ul. Rybaki 59 za rok 1973, t. 2, sygn. 434, s. 2.

1688121167175 , Korespondencja p. prof. Karola Górskiego dnia 7 IV 1987 r. przekazat Ks. Józefowi Grucy, odręczna notatka tzw. Calendarium z powstającego Zakładu Wychowawczego w Miejscu Piastowym. 
uczniów bł. B. Markiewicza i obejmował ich wykształcenie (matura), zawód (stolarz, szewc, gospodarz, ogrodnik itp.) pochodzenie (klasy społeczne). Pozostawione przez K. Górskiego luźne notatki dostarczają również informacji o wykazie literatury w prowadzonych badaniach naukowych. Autor odważnie przedstawił swoją interpretację zaistniałych spraw spornych pomiędzy św. Józefem Pelczarem a bł. B. Markiewiczem, sugerując ponowne badania w świetle ówczesnego prawodawstwa Kościoła rzymskokatolickiego.

Analizy obejmowały dane osobowe dwudziestu dziewięciu uczniów - wychowanków bł. B. Markiewicza. Badania przedstawił K. Górski w sposób tabelaryczny, podając u góry nazwiska i imiona uczniów. Lewa strona opracowania zawiera informacje dotyczące: miejsca urodzenia, roku urodzenia, środowiska społecznego, szkolnej edukacji, celu przybycia do zakładu, zajmowanego stanowiska w zakładzie, daty przybycia do Zakładu Wychowawczego, skąd uczeń dowiedział się o Miejscu Piastowym, czy składał śluby (kiedy, w jakim celu, na czyje ręce). Pytania w opracowanym przez siebie kwestionariuszu badawczym dały K. Górskiemu w miarę pełny przegląd środowiska osób, które zgłaszały się do Zakładu Wychowawczego bł. B. Markiewicza. Dane dotyczące miejsca urodzenia wskazują, że uczniowie przybywali do Zakładu Wychowawczego z następujących stron: Kongresówki, Galicji, Śląska, Pomorza, Wielkopolski. Odpowiedzi na pytania dotyczące środowiska społecznego uczniów wskazują na ich pochodzenie w większości chłopskie, czasem rzemieślnicze. Natomiast wykształcenie wychowanków jest zróżnicowane, bowiem spotyka wśród nich osoby z ukończoną szkołą ludową i gimnazjum. Celem przybycia większości z nich jest zostanie zakonnikiem i księdzem, poświęcanie się pracy na rzecz dzieci opuszczonych. Odpowiedzi na pytanie o stanowisko w Zakładzie Wychowawczym, określają, że wychowankowie po zdobyciu kwalifikacji pełnili funkcję: kierownika warsztatu krawieckiego, ślusarskiego, pracowni szewskiej lub ogrodnika itp. Wyniki badań wskazują, że wychowankowie przybywali do Zakładu Wychowawczego w przedziale czasowym od 1892 do 1918. Natomiast informację o istnieniu Zakładu Wychowawczego wychowankowie czerpali z różnych źródeł, m.in.: od proboszcza, od kolegi, z gazety, z pobytu w Krakowie. Byli również i tacy wychowankowie, którzy składali śluby na trzy lata, i wieczyste na ręce bł. B. Markiewicza w latach od 1898 do 1901, i inni, którzy ich nie składali ${ }^{17}$.

17 88121167175, Korespondencja p. prof. Karola Górskiego dnia 7 IV 1987 r. przekazat Ks. Józefowi Grucy, notatki na czterech stronach kartek papieru formatu A4. 
Wśród materiałów badawczych K. Górskiego znajduje się również podobny kwestionariusz badawczy, opracowany dla dziewięciu dziewcząt, przybyłych do powstającego Zgromadzenia Sióstr Michalitek. Omówię tylko wybrane odpowiedzi kwestionariusza badawczego w celu przedstawienia warsztatu naukowego, jaki prezentował K. Górski. Odpowiedzi te wskazują miejsca, np. miejsce urodzenia (Włodawa, Żyrardów) i następnie dzielnice (Kongresówka, Śląsk, Pomorze, Wielkopolska). Dziewczęta przybyły do Zakładu Wychowawczego w latach 1872-1886 i ich pochodzenie społeczne jest: chłopskie, robotnicze fabryczne, robotnicze wiejskie, stan średni i rzemieślnicze. Dziewczęta ukończyły szkołę ludową, szkołę miejską, a ich celem przybycia do Zakładu Wychowawczego jest realizacja powołania zakonnego. Przedział czasowy, w jakim przybyły do Zakładu Wychowawczego w Miejscu Piastowym, przypada na lata 1894-1902. Informacja o Zakładzie Wychowawczym pochodziła z różnych źródeł, np. od starszej siostry. Śluby zakonne czasowe lub wieczyste składały kandydatki do Zgromadzenia na ręce bł. B. Markiewicza w latach 1898-1902, chociaż były też dziewczęta, które ślubów nie składały ${ }^{18}$.

Przedstawione w skrócie badania, jakie przeprowadził K. Górski, dają świadectwo wysokiej miary warsztatu badawczego posiadanego przez naukowca. Postawione pytania i udzielone odpowiedzi dają obraz osób, przychodzących do Zakładu Wychowawczego, oraz ich postępu w zdobywanej wiedzy i rozwijanego życia duchowego.

Przechowywane w Archiwum Generalnym Zgromadzenia opracowanie sporządzone w formie maszynopisu pt. Zagadnienie świętości ks. Bronistawa Markiewicza powstało w lutym 1956 roku. K. Górski podaje w nim informację dotyczącą zagadnień związanych ze świętością i sposobom jej przejawiania wśród ludzi. Osoby święte są nam dobrze znane z różnych szczegółowych faktów z ich życia, niemniej jednak wśród ludzkiej słabości zdarza się, że zatracamy sens rzeczy istotnych. Natura ludzka wymaga łaski Bożej, która ją tak podnosi, że niedoskonałe narzędzie wykonuje plan Boży. Współczesna świętość polega na przeciwstawieniu słabej, widocznej, ludzkiej natury łasce niewidocznej, potężnej w swej mocy. Mówiąc o świętości, należy postawić pytanie o granicę, do której może sięgać ludzka słabość i kiedy przekrocze-

18 88121167175, Korespondencja p. prof. Karola Górskiego dnia 7 IV 1987 r. przekazat Ks. Józefowi Grucy, notatki na dwóch stronach kartek papieru formatu A4. 
nie jej leży w decyzji człowieka, czy Boga, który ostrzega człowieka poprzez swoje znaki ${ }^{19}$.

Bł. B. Markiewicz przewidywał, że zakładane przez niego Zgromadzenie zakonne podejmie się opiekuńczego wychowania dzieci i młodzież zaniedbanej moralnie i materialnie. Salezjanie zajmują się wychowaniem dzieci i młodzieży warstw średnich, a dla wychowania innych grup, np. młodzieży przestępczej, powinno być jeszcze inne zgromadzenie. Wśród części duchowieństwa w Przemyślu nie wierzono, że powstanie Zakład Wychowawczy w Miejscu Piastowym i nie sądzono, że będzie nowe Zgromadzenie zakonne. Jednak całkowite zawierzenie Bogu niedoskonałego narzędzia, jakim był bł. B. Markiewicz, daje gwarancję realizacji dzieła ${ }^{20}$.

K. Górski, pisząc o bł. B. Markiewiczu, twierdził, że umiłowanie dzieci opuszczonych w jego personalistycznej koncepcji było miarą miłości Boga, która na co dzień przekładała się na zachowanie czystości wiary i głęboką ufność. System bł. B. Markiewicza to system prewencji i uobecnionej asystencji, który odznaczał się prawdą życia, dobrocią i łagodnością. Te cechy bł. B. Markiewicz preferował i nimi emanował w kontaktach z młodzieżą, zdobywając ich serca; nigdy nie stosował kar cielesnych, a nie chcąc karać także słownie, zapobiegał złu łagodną perswazją. Bł. B. Markiewicz posiadał zdolności organizatorskie, które pomagały mu w codziennych zmaganiach. $\mathrm{Z}$ trudami borykał się do końca swych dni na ziemi, a były to też własne słabości: porywczość i gwałtowność w mowie i działaniu. Jako człowiek uzdolniony, bł. B. Markiewicz miał szeroką wiedzę o bogatych horyzontach, rozszerzał działalność wychowawczą, nie posiadając dostatecznej ilości przygotowanych i ugruntowanych wychowawców. Pomimo sięgania do granic swoich słabości i bezgranicznej ufności Bogu, bł. B. Markiewicz otrzymywał od Niego znaki pewności drogi, którą kroczył w swojej działalności i zdobył świętość życia ${ }^{21}$.

Rozpoznanie świętości osób, wśród których się żyje, nie zawsze jest trafne i zgodne z prawdą, ponieważ zdarzają się osoby, raczej negatywnie niż pozytywnie wyrażające się o innych. Pełnione dobro zazwyczaj jest niewidoczne, a towarzysząca każdemu człowiekowi słabość jest bardziej krzykliwa, i chętniej się o niej mówi. Dopiero dłuższa perspektywa czasu uwidacznia, jakie

1988121167175 , Korespondencja p. prof. Karola Górskiego dnia 7 IV 1987 r. przekazat Ks. Józefowi Grucy, zob. K. Górski, Zagadnienie świętości ks. Bronistawa Markiewi$c z a$, Toruń 1956, s. 1. (maszynopis)

20 Tamże, s. 4-5.

21 Tamże, s. 9-10. 
jest jego człowieczeństwo. Wtedy istotna jest pewna cecha postrzegania, którą potrafi się rozeznać i ukazać obiektywnie wyjątkowość i świętość osoby.

\section{Korespondencja Karola Górskiego}

Posiadane przez Archiwum Generalne Zgromadzenia listy kierowane do K. Górskiego, szczególnie przez ks. W. Moroza CSMA, świadczą o tematyce omawianych spraw związanych z historią Zgromadzenia Księży Michalitów i osobą bł. B. Markiewicza. List ks. W. Moroza CSMA z 5 sierpnia 1975 r. mówi o przesłaniu artykułu Profesorowi do Torunia, artykułu dotyczącego świętości bł. B. Markiewicza. Dalsza treść listu informuje, że jego autor, ks. W. Moroz CSMA, planuje wyjazd do Torunia w drugiej połowie sierpnia br. i myśli o nawiązaniu osobistego kontaktu z K. Górskim. Na miejscu planuje omówić kwestie dotyczące dostarczenia dalszych materiałów o bł. B. Markiewiczu ${ }^{22}$.

Kolejny list dotyczy informacji o wysyłce do K. Górskiego obiecanych materiałów na temat bł. B. Markiewicza. Konkretnie chodzi o dwa artykuły ks. prof. Aleksego Petraniego, drukowane w czasopiśmie „Nasza Przeszłość” i maszynopisie, który jeszcze nie był publikowany. Końcowa część listu podaje do wiadomości adresata informację o mającym powstać nowym opracowaniu w ujęciu ks. prof. A. Petraniego, dotyczącym początków Zgromadzenia Księży Michalitów ${ }^{23}$.

Następny materiał badawczy to list K. Górskiego, który zawiera głębokie przekonanie o świętości bł. B. Markiewicza i o potrzebie takiego wzoru postępowania na obecne czasy. Autor podaje trzy argumenty, potwierdzające to twierdzenie: 1) właściwie pojęte ubóstwo w sposób funkcjonalny z uwzględnieniem ludzi, dla których się pracuje; 2) ufność w sposób nieograniczony w Bożą opiekę nad dziełem, które tworzył pomimo ludzkich niepewności; 3) trudne, a nawet bolesne posłuszeństwo wobec ordynariusza św. J. Pelczara, ale nie ślepe posłuszeństwo, bo zawarte w nadprzyrodzonej roztropności. Wszystko to składa się na heroiczność cnót, które cechowały bł. B. Markiewi-

2288121167175 , Korespondencja p. prof. Karola Górskiego dnia 7 IV 1987 r. przekazat Ks. Józefowi Grucy, zob. W. Moroz, ks. CSMA, Wielce Szanowny Panie Profesorze, Struga, 5 sierpień $1975 \mathrm{r}$.

${ }^{23}$ 88121167175, Korespondencja p. prof. Karola Górskiego dnia 7 IV 1987 r. przekazat Ks. Józefowi Grucy, zob. W. Moroz, ks. CSMA, Wielce Szanowny Panie Profesorze!, Struga, 9 listopad $1975 \mathrm{r}$. 
cza, jego gorącą miłość Boga i bliźniego oraz nieprzeciętną inteligencję. Rdzeniem religijności bł. B. Markiewicza jest heroiczna miłość Boga i bliźniego w najuboższych i najbardziej opuszczonych środowiskach. Autor listu wyjaśnia wyżej wymienione argumenty w sposób następujący:

- terenem działalności bł. B. Markiewicza było Pogórze Galicji, gdzie ziemia była nieurodzajna i brakowało przemysłu. Przeludnienie, które panowało $\mathrm{w}$ ówczesnych czasach, powodowało nędzę i panoszenie się pijaństwa. Probostwo w Miejscu Piastowym, którego podjął się bł. B. Markiewicz, było pracą Salezjanina przybyłego z Włoch. Bł. B. Markiewicz doskonale wiedział o wyższej stopie życia we Włoszech i Niemczech oraz odpowiednim wyżywieniu, ale podjął się życia wśród ludności chłopskiej i postanowił żyć tak jak okoliczni mieszkańcy. Również jego praca stała się ukierunkowana na młodzież ubogą i dlatego podążał w kierunku ich wychowania oraz kształcenia. Postawa, jaką przyjął, jest wyrazem służby w kraju ubogim wśród ludności biednej;

- ufność bł. B. Markiewicza w opiekę Opatrzności przy prowadzonym dziele była nieograniczona i doznawał wsparcia najczęściej od najbiedniejszych. Bogaci zarzucali bł. B. Markiewiczowi społeczny radykalizm i byli nieufni wobec prowadzonej działalności;

- posłuszeństwo ordynariuszowi św. J. Pelczarowi było trudne, heroiczne i bolesne ze względu na gwałtowny i porywczy charakter bł. B. Markiewicza. Lata pracy nad sobą zmieniły jego postawę i posłusznie przyjął zarządzenie z 13 grudnia 1902 r., które uniemożliwiało założenie nowego Zgromadzenia zakonnego i wydalenie kandydatki na siostrę zakonną, Annę Woźną. Postawa bł. B. Markiewicza potwierdzała, że nie przestaje wierzyć w to, że dzieło to jest Boże i cieszy się opieką Opatrzności ${ }^{24}$.

Jeszcze jeden list K. Górskiego, który tu przytoczę, świadczy o znajomości bł. B. Markiewicza i jego duchowości. Autor listu najpierw wyjaśnia, że osoby oddane Bogu i świątobliwe nie mogą kłamać świadomie, a jeżeli to się

2488121167175 , Korespondencja p. prof. Karola Górskiego dnia 7 IV 1987 r. przekazat Ks. Józefowi Grucy, list zaczyna się następującymi słowami: Niniejszy list postulacyjny w sprawie beatyfikacji Księdza Bronistawa Markiewicza, (...) i podpisany został: Dr hab. Karol Górski em. Profesor zwyczajny Uniwersytetu Mikotaja Kopernika w Toruniu, Cztonek - Korespondent bytej Polskiej Akademii Umiejętności i Corresponding Fellow Medieval Academy of America. 
zdarza, to wynika to z leżących przyczyn poza ich świadomością. Wyjaśnia również rolę, jaką spełniają tzw. „osoby trzecie”, które same pozostają w półcieniu, a potrafią skutecznie wpływać na innych. Następnie K. Górski określa duchowość bł. B. Markiewicza jako połączenie duchowości ignacjańskiej z elementami duchowości salezjańskiej ${ }^{25}$.

\section{WNIOSKI}

Każda epoka odznacza się swoimi świętymi. Na ich tle jawią się wizerunki osób, które wyróżniają się w sposób zasadniczy. K. Górski wiedział, jakie przymioty wyrażają człowieka wyjątkowego, gdy opisywał żywoty świętych, np. hagiografie świętych żyjących w średniowieczu. Twórczość naukowa K. Górskiego zawężona do działalności Zgromadzenia Księży Michalitów, wpisała się na trwałe w dzieje historii i przez to zaznaczyła podstawy swego istnienia i uwierzytelniła je, wynosząc do chwały ołtarzy bł. B. Markiewicza. To dowodzi, że wiedza ta była konieczna, ponieważ rys biograficzny Błogosławionego i Zgromadzenie zakonne w naukowych opracowaniach tworzyły podstawy, do których można się odwoływać po dzień dzisiejszy. K. Górski, opisując postać bł. B. Markiewicza, nakreślił wizerunek człowieka świętego i nie pomylił się w swoich ocenach, takim bowiem był rzeczywiście.

Odniesienie się do osoby bł. B. Markiewicza i jego świętości ukazało nowy sposób na doskonałość, którą można było realizować w XIX i XX w. oraz kontynuować w XXI wieku. Poszukiwania świętości, jak zauważa K. Górski, w osobie bł. B. Markiewicza były specyfiką epoki, której przykładem w sztuce kościelnej jest eklektyzm, wyróżniający się mieszanką różnych stylów.

K. Górski, posiadając znakomity warsztat naukowy i ogromną znajomość życia duchowego, daje świadectwo własnym życiem, opartym na ewangelicznym przesłaniu. Jego troską staje się wspólnota małżeńska, modlitwa różańcowa, rodzina i działalność charytatywna, co potwierdza się we współczesnej działalności Kościoła rzymskokatolickiego w Polsce. Należy sądzić, że wartości, które wyznawał Profesor, znajdują swoją aktualność we współczesnym życiu Kościoła i są nadal pielęgnowane. Profesor, czerpiąc z tradycji dziejów duchowości w Polsce, trafnie odczytał wartości aktualne i obecne w życiu Ko-

25 88121167175, Korespondencja p. prof. Karola Górskiego dnia 7 IV 1987 r. przekazat Ks. Józefowi Grucy, list skierowany do ks. Andrzeja Swidy SDB, zob. K. Górski, Czcigodny Księże Profesorze, Toruń, 21 czerwiec 1980, s. 1. 
ścioła. Dużo się mówi o rodzinie, aby była „Bogiem silna”, modliła się wspólnie na różańcu i troszczyła o ludzi biednych potrzebujących pomocy - stąd aktualne akcje charytatywne realizowane przez Kościół.

Korespondencja, świadcząca o żywym kontakcie Zgromadzenia Księży Michalitów z K. Górskim, przynosi chlubne świadectwo jego obecności w życiu Zgromadzenia zakonnego i trwającemu wówczas procesowi beatyfikacyjnemu bł. B. Markiewicza. Zgromadzenie Księży Michalitów posiadało wyjątkowego na ówczesne czasy badacza własnej historii i orędownika w słusznej sprawie pewności i świętości, bł. B. Markiewicza. Naukowe badania Profesora przyniosły pozytywne wnioski i przyczyniły się do uznania przez Kościół świętości życia bł. B. Markiewicza w stopniu heroicznym.

Roman Majka

Notes of Karol Gorski in archival collections of the Archive of the General Congregation of Saint Michael the Archangel in Marki regarding Blessed Bronislaw Markiewicz and his pupils.

Su m m a ry

Professor Karol Gorski (1903-1988) was an expert on spirituality in Poland, and an author of many publications, such as 'An outline of the history of spirituality in Poland' published in Krakow in 1986. Professor was inspired by the Michaelite spirituality, while exploring the life and work of the founder of Michaelite Fathers - Blessed Father Bronislaw Markiewicz (1842-1912). Presently, Father Markiewicz's selected academic works and research material are preserved in Archive of the General Congregation of St. Michael the Archangel in Marki near Warsaw. Among many Gorski's publications is an article 'The inner life of Fr. Bronislaw Markiewicz' published in the journal 'Our Past', Vol. 23, 1966, pp. 239-278. Remaining in the collection are notes handwritten by Gorski kept as Calendarium, which attest to his thoroughness and diligence in research. Collected materials carefully prepared with the aim to enable most accurate reconstruction of the events of the Education Service of Miejsce Piastowe describe the life and work of the Blessed Markiewicz and his first pupils. Sustained contact of Gorski with Michaelite Fathers is confirmed in preserved correspondence, especially the letters of Fr. Valerian Moroz CSMA ${ }^{26}$ (1919-2005). Professor, drawing from the history of spirituality in Poland, read the current issues of the Church and was highly respectful of family values and providing care of poor people in need of help. 